\title{
Validade e reprodutibilidade do Teste de Caminhada da Milha para idosas de 70 a 79 anos
}

\author{
Validity and reliability of the one-mile walk test (The Rockport \\ Fitness Walk Test) among 70-to-79 year old women
}

1 Universidade Federal de Santa Catarina. Centro de Desportos. Mestrado em Educação Física. Florianópolis, SC. Brasil. 2008.

Orientador: Profa. Dra. Rosane Carla Rosendo da Silva
Resumo - O objetivo desta pesquisa foi verificar a reprodutibilidade e a validade cruzada do Teste de Caminhada da Milha (TCM), proposto por Kline et al. (1987), como preditor do consumo máximo de oxigênio ( $\dot{\mathrm{V}} \mathrm{O}_{2}$ máx), em mulheres com idade entre 70-79 anos. A pesquisa contou com uma amostra não-probabilística intencional constituída por 30 idosas saudáveis de Florianópolis/SC. A coleta de dados foi dividida em três etapas: 1) aplicação de questionários sociodemográfico, de prontidão para Atividade Física (PAR-Q) e do nível de Atividade Física (IPAQ). Mensuração de variáveis antropométricas e execução da primeira avaliação do TCM, além da familiarização com a esteira ergométrica e analisador de gases para medida direta do $\dot{\mathrm{VO}_{2}}$ máx (K4 b ${ }^{2}$ - COSMED) para o teste de exercício cardiopulmonar (TECP); 2) realização do TECP, seguindo o protocolo do tipo rampa, com intensidade de trabalho de $2,4 \mathrm{~km} \cdot \mathrm{h}^{-1}$ a $5,6 \mathrm{~km} \cdot \mathrm{h}^{-1}$ e inclinação de $0 \%$ a $15 \%$; 3) realização do segundo TCM. Foram utilizados os critérios de validação cruzada sugeridos por Lohman (1992) e as análises foram realizadas nos programas SPSS (v. 7.5) e MedCalc (v. 9.1), adotando-se um nível de significância de 5\%. Com relação à reprodutibilidade, as equações generalizada (EG) e específica para mulheres (EEM) apresentaram um alto Coeficiente de Correlação Intraclasse - $\mathrm{CCI}=0,942$ e 0,948 (p<0,001) para o $\dot{V O}_{2}$ máx e baixo erro padrão de estimativa (entre 1,14 e $\left.1,48 \mathrm{ml} \mathrm{O}_{2} \cdot \mathrm{kg}^{-1} \cdot \mathrm{min}^{-1}\right)$. Quanto à validade, houve subestimação do $\dot{V} \mathrm{O}_{2}$ máx predito $\left(\mathrm{EG}=17,11 \pm 5,97 \mathrm{ml} \mathrm{O} \cdot \mathrm{kg}^{-1} \cdot \mathrm{min}^{-1} ; \mathrm{EEM}=17,15 \pm 4,99 \mathrm{ml}\right.$ $\mathrm{O}_{2} \cdot \mathrm{kg}^{-1} \cdot \mathrm{min}^{-1} \mathrm{vs} \dot{\mathrm{VO}}$ máx medido $\left.=26,67 \pm 3,53 \mathrm{mlO}, \cdot \mathrm{kg}^{-1} \cdot \mathrm{min}^{-1}\right)(\mathrm{p}<0,001)$ pelas duas equações do TCM, além de baixos valores de correlação entre $\dot{\mathrm{V}} \mathrm{O}_{2}$ max medido e predito ( $\mathrm{r}=0,488$ e 0,471). As equações apresentaram um erro constante alto $\left(-9,56\right.$ e $\left.-9,53 \mathrm{ml} \mathrm{O}_{2} \cdot \mathrm{kg}^{-1} \cdot \mathrm{min}^{-1}\right)$, havendo apenas $16,7 \%$ de concordância entre os métodos. Desta forma, o TCM se mostrou reprodutível, contudo, não válido para estimar o $\dot{V} \mathrm{O}_{2}$ máx de idosas ativas de idosas ativas com idade entre 70 e 79 anos.

Palavras-chave: Idosos; Teste de Caminhada da Milha; Consumo Máximo de Oxigênio; Validade; Reprodutibilidade.

Abstract - The purpose of this study was to verify the reliability and concurrent validity of the One-Mile Walk Test (OMWT) (The Rockport Fitness Walk Test, Kline et al., 1987), as a preditor of the maximal oxygen consumption ( $\dot{\mathrm{VO}} 2 \max )$ among women aged 70 to 79 years. The study used a convenient sample, composed by 30 healthy seniors from Florianópolis, SC. Data collection was structured in three phases: 1) answering questionnaires on sociodemographics, on readiness for physical activity (PAR-Q) and on physical activity level (IPAQ). Anthropometric variables were measured and the participant performed the first evaluation of the RFWT. Afterwards, the subject visited the laboratory for a treadmill walk and for a trial of the equipments (K4 b2 - COSMED) to be used during the stress test (ST) for directly measuring the $\mathrm{VO}_{2}$ max; 2) the seniors performed the ST following an incremental test protocol, from $2.4 \mathrm{~km} . \mathrm{h}^{-1}$ to 5.6 $\mathrm{km} . \mathrm{h}^{-1}$ with grades varying from $0 \%$ to $15 \%$; 3 ) the second RFWT. The statistical analyses included the criteria suggested by Lohman (1992) for validity and the procedures were performed using the SPSS (v. 7.5) and MedCalc (v. 9.1). The level of significance was established at 5\%. For reliability, the generalized (GE) and sex-specific equations (SSE) presented high intraclass correlation coefficients (ICC $=0.942$ and $0.948, p<0,001$ ) for predicted $\dot{V} \mathrm{O}_{2}$ max and low standard error of the estimate $\left(1.14\right.$ and $\left.1.48 \mathrm{ml} \mathrm{O}_{2} \cdot \mathrm{kg}^{-1} \cdot \mathrm{min}^{-1}\right)$. For validity, the predicted $\mathrm{VO}_{2}$ max was underestimated by both equations $\left(\mathrm{GE}=17.11 \pm 5.97 \mathrm{ml} \mathrm{O} . \mathrm{kg}^{-1} \cdot \mathrm{min}^{-1} ; \mathrm{SSE}=17.15 \pm 4.99 \mathrm{ml}\right.$ $\mathrm{O}_{2} \cdot \mathrm{kg}^{-1} \cdot \mathrm{min}^{-1}$ vs $\dot{\mathrm{VO}} \mathrm{O}_{2}$ max measured $\left.=26.67 \pm 3.53 \mathrm{mlO}_{2} \cdot \mathrm{kg}^{-1} \cdot \mathrm{min}^{-1}\right)(\mathrm{p}<0.001)$, and low correlation coeficients $(r=0.488$ and 0.471$)$ between predicted and measured $\dot{V} \mathrm{O}_{2}$ max were observed. The equations presented high constant error (-9.56 and $\left.-9.53 \mathrm{ml} \mathrm{O}_{2} \cdot \mathrm{kg}^{-1} \cdot \mathrm{min}^{-1}\right)$, with only $16.7 \%$ of agreement between the methods. Therefore, the RFWT was reliable, however, not valid for predicting $\dot{\mathrm{V}} \mathrm{O}_{2}$ max among active elderly women aged 70 to 79 years.

Key words: Elderly; The Rockport Fitness Walk Test; Maximal Oxygen Uptake; Validity; Reliability. 